\title{
Analysis of Passenger Satisfaction Level of Service And Facilities of Electric Rail Train (KRL) Commuter Line Route Bekasi - Manggarai
}

\author{
Andri Irfan Rifai and Yuditami Iressa Fajriliani \\ Faculty of Engineering, University Mercu Buana Jakarta, Indonesia \\ andriirfan@yahoo.com, iressafajr@gmail.com
}

\begin{abstract}
The train is considered to act as strategic public transport because of its ability to reduce congestion in urban areas. Various modes of transportation are in a race - a race to improve the quality of service that requires rail freight also needs to improve in all areas. Service is the main priority which is used as a benchmark in competitive advantages and facilities are factors that affect the services provided by the transport company. This is the underlying researchers to conduct research on passenger satisfaction ratings on the level of service performance and service facilities Commuter Line KRL Bekasi - Manggarai and to determine the factors affecting passenger satisfaction. Data obtained in the form of a survey by questionnaire online delivery methods. Methods of data analysis software used isms. Excel and SPSS software for statistical testing. The conclusions of the research by the method of Customer Satisfaction Index (CSI) obtained a passenger satisfaction index score of $76.11 \%$. It is stated that the passengers very satisfied with the performance of services and facilities service station Commuter Line KRL Bekasi - Manggarai, only for the suitability of the train arrival and departure needs to be improved.
\end{abstract}

Keywords: Satisfaction, KRL Commuter Line, CSI

\section{Introduction}

Trains are considered to have several advantages over other public transportation, including the accuracy and speed of travel time, connectivity, compliance seating, ease of buying tickets, as well as the facilities available at the station or the train, KRL (Light rail) Commuter Line is one type of public transport is very desirable communities in Greater Jakarta. In addition to visits from the advantages owned railway, there are other considerations that attract people to use the Commuter Line KRL ie, at affordable rates.

In recent years, various modes of transport are in a race - a race to improve the quality of service which requires the need to improve rail transport in all fields. Service is the main priority which is used as a benchmark in competitive advantages and facilities are factors that affect the services provided by the transport company.

PT Kereta Api Indonesia, which is currently the only company that is engaged in the provision of services rail transport service, along with its subsidiary PT Kereta Commuter Indonesia is required to continue to improve in an effort to improve the delivery of public services and improve operational systems in order to produce the maximum satisfaction to service users or customers.

Based on the above, it is necessary to make a study in the form of thesis entitled "Analysis of Passenger Satisfaction Level Of Service Light rail (KRL) and Commuter Line These amenities Bekasi Station - Manggarai".

Based on the above, can be formulated issues to be used as materials research, among other things:

a. How ratings passenger satisfaction with services and facilities to the Commuter Line KRL Bekasi Manggarai?

b. What are the factors that affect the performance of services and facilities to the Commuter Line KRL Bekasi Manggarai?

The objectives of this study are as follows:

a. Knowing the level of passenger satisfaction with the services and facilities the Commuter Line KRL Bekasi Manggarai.

b. Identify the factors that affect the performance of services and facilities to the Commuter Line KRL Bekasi Manggarai. 


\section{Review of Literature}

\subsection{Quality of Service}

Quality of service is defined as any consumer perceptions about a quality organization as technical or functional, product and services, delivery of services and environmental services, or reliability, responsiveness, empathy, assurance and tangibles incorporated in a service experience. The quality of a service is determined by how consumers view these services in accordance with the perception of each, according to Brady and Cronin. [1]

\subsubsection{Model Serviqual}

Other service quality model is a model developed by Parasuraman et. al. (1988) which is also called the SERVQUAL. Parasuraman et. al. (1988) found 10 dimensions evaluating consumer criteria in determining the quality of service that tangibles. Reliability, Responsiveness, Competence, Courtesy, Credibility, Security, Access, Communication, Understanding the customer.

However, after further investigation, 10 of these dimensions into five dimensions. Dimensions tangibles, reliability, and responsiveness is maintained, then the other seven dimensions together and turned into a dimension of assurance and empathy. The fifth dimension then becomes dimensions of SERVQUAL. [2]

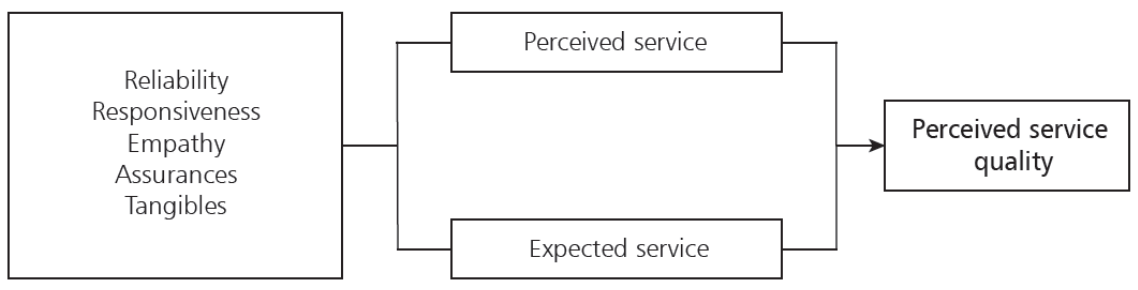

Figure 1. Model Servqual

\subsubsection{Nordic Model}

Source: Polyakova \& Mirza, 2015

At first there were two primary dimensions in service quality. Grönroos (in Franciscus, Sukapto, \& Sitompul, 2012) says that the dimensions of service quality consists of the functional quality and technical quality. Grönroos model is then referred to as the Nordic persepective. [2]

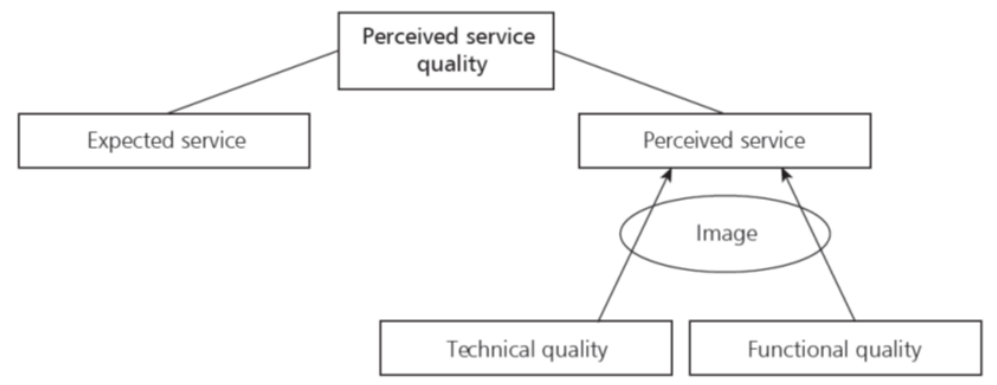

Figure 2. Model Nordic

\subsubsection{Model Hierarchy}

Source: Polyakova \& Mirza, 2015

This method has the attributes are balanced to measure the quality of services at the traditional service company or any company that uses the services of consumer interaction for equipment (Pollack, 2009). Hierarchical Approach excess compared with the method of measuring the quality of other services is that this method also takes into account quality outcome. [2] 

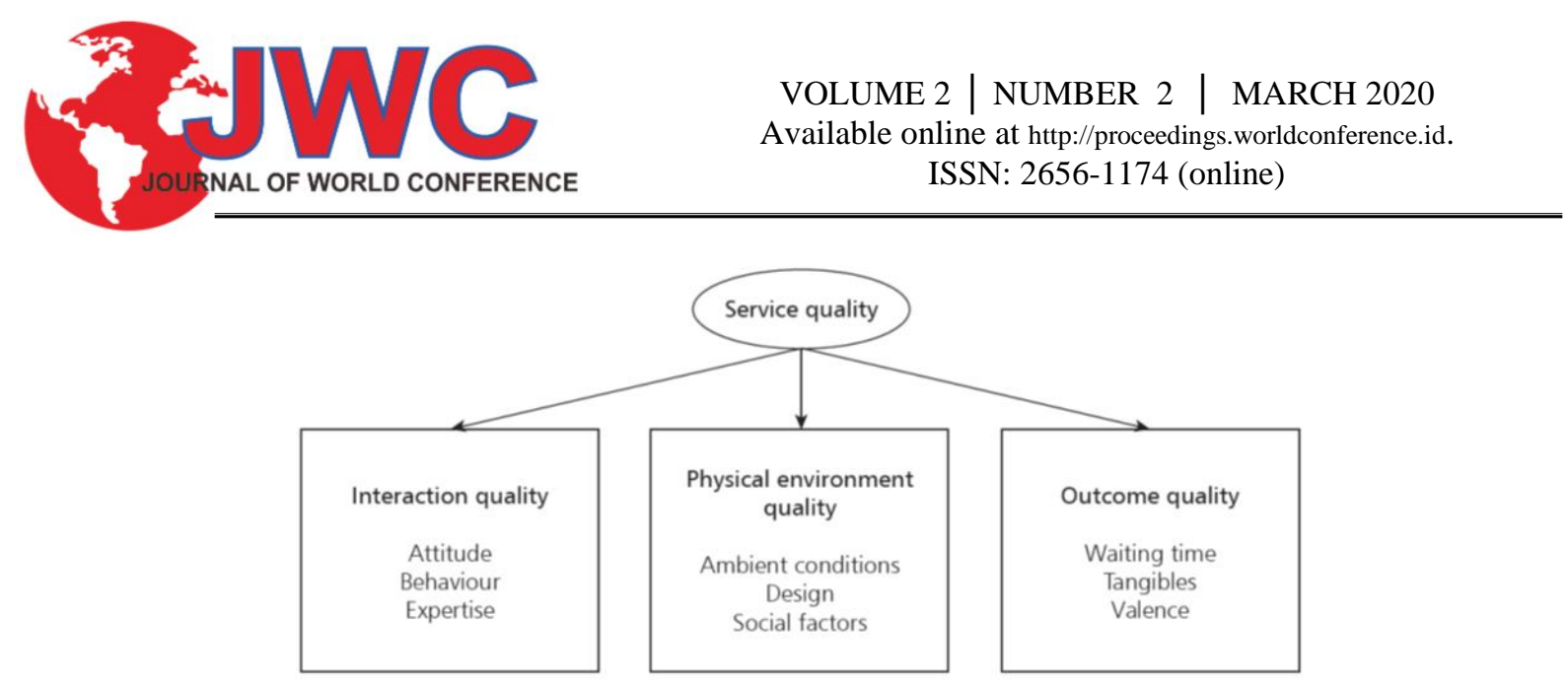

Figure 3. Model Hierarchy

\subsubsection{Multilevel Model}

Source: Polyakova \& Mirza, 2015

Multilevel models introduced many dimensions of service quality perceptions or in other words, the retail service quality is viewed as the highest factor defined in the 2-level attributes. [2]

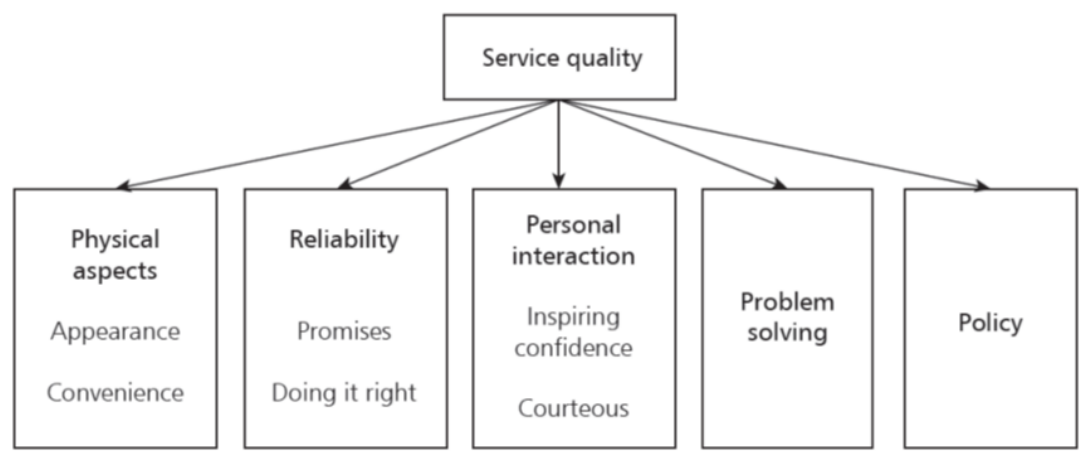

Figure 4. Multilevel Model

Source: Polyakova \& Mirza, 2015

\subsection{Customer Satisfaction}

Satisfaction is the level of one's feelings after comparing the performance or results that he felt with his expectations. If the performance is as expected, then the customer will be satisfied. Conversely, if the performance below expectations, then the customer will be very disappointed. Whereas when performance exceeds expectations, the customer will be very satisfied because customer expectations can be shaped by past experiences, comments from relatives as well as appointments and information from various media.

Based on the description above, it can be concluded that satisfaction is feeling happy or satisfied individuals because between expectations and reality in wear and the services provided are met.

\subsection{Understanding Light rail (KRL)}

Light rail or abbreviated KRL, a moving train with electric motor propulsion system. In Indonesia, the electric train mainly found in the Greater Jakarta area, and an airport commuter trains.

\subsection{Statistical Product and Service Solutions (SPSS)}

Tests on this study, carried out using the software Statistical Productions and Service Solutions, commonly known by the SPSS, a processing program of statistical data from the application model descriptive statistics (mean, median, mode, quartiles, percentiles, range, distribution, variance, standard deviation, standard error, the slope value, etc.), statistical parametric (t-test, correlation, regression, aNOVA, etc.), as well as non-parametric statistical (test crosstab, binomial, chi-square, Kolmogorov Smirnov, and etc). After the data obtained in this study through a questionnaire respondents, the data is then tested by using SPSS to test the validity and reliability.

\section{Methodology}

Here is a flow chart of research that will be done: 


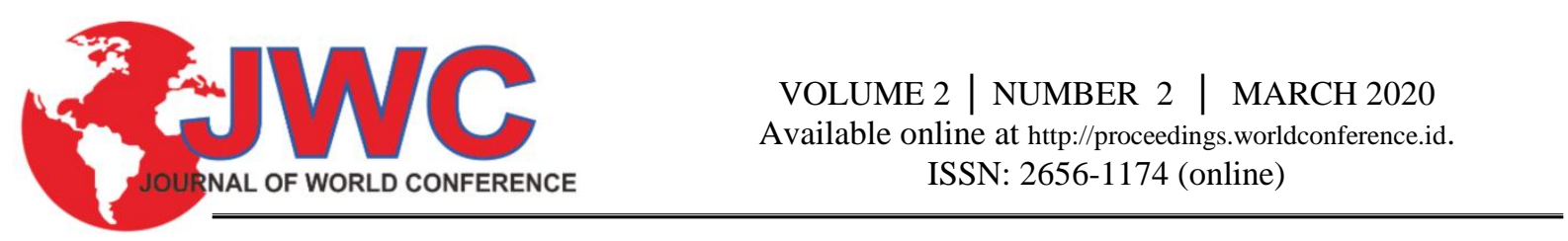

\subsubsection{Important performance analysis}

Importance Performance Analysis (IPA) is used to measure the relationship between consumer perceptions and priorities for improving the quality of products / services also known as the quadrant analysis. IPA combines measurements of factors importance and satisfaction level in 2-dimensional graphics ease of explanation data. This concordance rate determines the priority order of service affecting passenger satisfaction.

In this research there are two variables, the variables $\mathrm{x}$ and $\mathrm{y}$ variables which:

a. Variable $\mathrm{X}$ is the level of quality of service

b. $\mathrm{Y}$ is the level of passenger satisfaction

\subsubsection{Chi square test}

Chi Square test is a non-parametric statistical tests that can be applied to the test data nominal and nominal categorical. Chi Square test is used to examine the relationship between variables.

Basis for a decision:

By comparing the Chi Square count with Chi Square table

1. If the Chi Square count <Chi Square table. H0

2. If the Chi Square test> Chi Square table. H0 is rejected

\section{Analysis and Results}

Validity testing is done to determine the level of conformity among the items of research instruments, where a decision on an item can be considered valid question if rhitung> rtabel. Values obtained from Table Distribution rtabel rtabel Value Significance 5\% and 1\% to the value of $\mathrm{N}$ is the number of respondents is 100 people and the significant value of 5\%, obtained rtabel 0.195 . Testing the validity of using the Pearson product moment in SPSS.

The item questionnaire regarding service performance variable (variable $\mathrm{X}$ ) is valid or invalid is presented as in the following table.

Table 1. Results of Test Validity Service Performance

\begin{tabular}{ccccc}
\hline No. & variable name & R Count & R Table & Information \\
\hline 1 & X1B & .607 & 0.195 & valid \\
\hline 2 & X1M & .493 & 0.195 & valid \\
\hline 3 & X2B & .563 & 0.195 & valid \\
\hline 4 & X2M & 0.659 & 0.195 & valid \\
\hline 5 & X3B & 0.605 & 0.195 & valid \\
\hline 6 & X3M & 0,700 & 0.195 & valid \\
\hline 7 & X4B & 0.665 & 0.195 & valid \\
\hline 8 & X4M & .663 & 0.195 & valid \\
\hline 9 & X5B & 0.567 & 0.195 & valid \\
\hline 10 & X5M & 0.506 & 0.195 & valid \\
\hline 11 & X6B & 0.634 & 0.195 & valid \\
\hline 12 & X6M & 0.524 & 0.195 & valid \\
\hline 13 & X7B & .673 & 0.195 & valid \\
\hline 14 & X7M & 0.672 & 0.195 & valid \\
\hline 15 & X8B & 0.593 & 0.195 & valid \\
\hline 16 & X8M & 0,641 & 0.195 & valid \\
\hline 17 & X9B & 0,687 & 0.195 & valid \\
\hline 18 & X9M & .720 & 0.195 & valid \\
\hline 19 & X10B & .614 & 0.195 & valid \\
\hline 20 & X10M & 0.715 & 0.195 & valid \\
\hline & & & $504 r$ & Processed
\end{tabular}

\begin{tabular}{ccccc}
\hline No. & variable name & R Count & R Table & Information \\
\hline 21 & $\mathrm{X} 11 \mathrm{~B}$ & 0,745 & 0.195 & valid \\
\hline 22 & $\mathrm{X} 11 \mathrm{M}$ & 0,702 & 0.195 & valid \\
\hline 23 & $\mathrm{X} 12 \mathrm{~B}$ & .773 & 0.195 & valid \\
\hline 24 & $\mathrm{X} 12 \mathrm{M}$ & 0,747 & 0.195 & valid \\
\hline 25 & $\mathrm{X} 13 \mathrm{~K}$ & .609 & 0.195 & valid \\
\hline 26 & $\mathrm{X} 14 \mathrm{~K}$ & 0.647 & 0.195 & valid \\
\hline 27 & $\mathrm{X} 15 \mathrm{~K}$ & .730 & 0.195 & valid \\
\hline 28 & $\mathrm{X} 16 \mathrm{~K}$ & 0,629 & 0.195 & valid \\
\hline 29 & $\mathrm{X} 17 \mathrm{~K}$ & .737 & 0.195 & valid \\
\hline 30 & $\mathrm{X} 18 \mathrm{~K}$ & .748 & 0.195 & valid \\
\hline 31 & $\mathrm{X} 19 \mathrm{~K}$ & 0.785 & 0.195 & valid \\
\hline 32 & $\mathrm{X} 20 \mathrm{~K}$ & 0,646 & 0.195 & valid \\
\hline 33 & $\mathrm{X} 21 \mathrm{~K}$ & 0.685 & 0.195 & valid \\
\hline 34 & $\mathrm{X} 22 \mathrm{~K}$ & 0.457 & 0.195 & valid \\
\hline 35 & $\mathrm{X} 23 \mathrm{~K}$ & 0.608 & 0.195 & valid \\
\hline 36 & $\mathrm{X} 24 \mathrm{~K}$ & 0,622 & 0.195 & valid \\
\hline 37 & $\mathrm{X} 25 \mathrm{~K}$ & .561 & 0.195 & valid \\
\hline 38 & $\mathrm{X} 26 \mathrm{~K}$ & 0.658 & 0.195 & valid \\
\hline 39 & $\mathrm{X} 27 \mathrm{~K}$ & 0.683 & 0.195 & valid \\
\hline & & & &
\end{tabular}

Source: Processed Data Researcher, 2019

Based on Table 1 are known from the 39 item questionnaire on the statement of service performance variable (variable $\mathrm{X}$ ) has a value rhitung> rtabel indicates that the statement items are considered as "valid".

To determine whether an item questionnaire statement on passenger satisfaction variable $(\mathrm{Y})$ is valid or invalid is presented in the following table. 
Table 2. Results of Test Validity Importance

\begin{tabular}{ccccc}
\hline No. & variable name & R Count & R Table & Information \\
\hline 1 & Y1 & 0.752 & 0.195 & valid \\
\hline 2 & Y2 & 0.803 & 0.195 & valid \\
\hline 3 & Y3 & .851 & 0.195 & valid \\
\hline 4 & Y4 & .846 & 0.195 & valid \\
\hline 5 & Y5 & .684 & 0.195 & valid \\
\hline 6 & Y6 & 0,813 & 0.195 & valid \\
\hline 7 & Y7 & 0.827 & 0.195 & valid \\
\hline 8 & Y8 & 0,812 & 0.195 & valid \\
\hline 9 & Y9 & 0.858 & 0.195 & valid \\
\hline 10 & Y10 & 0.822 & 0.195 & valid \\
\hline 11 & Y11 & 0,782 & 0.195 & valid \\
\hline 12 & Y12 & .890 & 0.195 & valid \\
\hline 13 & Y13 & .798 & 0.195 & valid \\
\hline 14 & Y14 & .873 & 0.195 & valid \\
\hline & & & S0urce
\end{tabular}

\begin{tabular}{ccccc}
\hline No. & variable name & R Count & R Table & Information \\
\hline 15 & Y15 & .903 & 0.195 & valid \\
\hline 16 & Y16 & 0.823 & 0.195 & valid \\
\hline 17 & Y17 & .863 & 0.195 & valid \\
\hline 18 & Y18 & .787 & 0.195 & valid \\
\hline 19 & Y19 & .851 & 0.195 & valid \\
\hline 20 & Y20 & 0,782 & 0.195 & valid \\
\hline 21 & Y21 & 0.831 & 0.195 & valid \\
\hline 22 & Y22 & .810 & 0.195 & valid \\
\hline 23 & Y23 & 0.899 & 0.195 & valid \\
\hline 24 & Y24 & 0.911 & 0.195 & valid \\
\hline 25 & Y25 & 0.831 & 0.195 & valid \\
\hline 26 & Y26 & 0.886 & 0.195 & valid \\
\hline 27 & Y27 & 0.883 & 0.195 & valid \\
\hline & & & &
\end{tabular}

Source: Processed Data Researcher, 2019

According to the table 2. note of 27 item questionnaire statement on the variable of interest (Y) has a value rhitung > rtabel indicates that the item of the statement can be said to "Valid". Therefore, all items instrument in this study can be used.

\subsection{Test Reliability}

The test is performed to determine keterandalannya instrument to measure the level of consistency of respondents in answering questions in the questionnaire. Reliability testing is done by comparing the value of Cronbach's Alpha of the data processing, whereby if the value of Cronbach's Alpha> 0.6, the reliable / consistent and if the value of Cronbach's Alpha <0.6, it is not reliable / inconsistent. Results of testing the reliability of research instrument or questionnaire on service performance variable (variable X) can be presented in the following table:

Table 3. Services Performance Test Reliability

\begin{tabular}{rr}
\hline \multicolumn{2}{c}{ Reliability Statistics } \\
\hline Cronbach's Alpha & N of Items \\
\hline 0.963 & 39 \\
\hline
\end{tabular}

Source: Processed Data Researcher, 2019

Based on table 4.3, note the value of Cronbach's Alpha service performance variable (variable X) of 0963, because the value of Cronbach's Alpha> $0.6(0963>0.6)$ so that the questionnaire is reliable / consistent.

In addition, the results of testing reliability of research instrument or questionnaire on a variable rate of interest (variable Y) are presented in the following table:

Table 4. Results of Test Reliability Importance

\begin{tabular}{cc}
\hline \multicolumn{2}{c}{ Reliability Statistics } \\
\hline Cronbach's Alpha & N of Items \\
\hline .979 & 27 \\
\hline
\end{tabular}

Source: Processed Data Researcher, 2019

Based on table 4.4, note the value of Cronbach's Alpha passenger satisfaction variable (Y) obtained a value of 0979, because the value of Cronbach's Alpha> 0.6 (0979> 0.6) so that the questionnaire is reliable / consistent. Thus, the research instrument used in this study expressed a reliable or trustworthy.

From table 4.3 and table 4.4, it can be deduced as follows:

Table 5. Test Results Rliabilitas

\begin{tabular}{cccc}
\hline No. & variables & R arithmetic & Information \\
\hline A & Service performance & $0.963>0.6$ & Reliable \\
\hline B & level Kependalan & $0.979>0.6$ & Reliable \\
\hline \multicolumn{4}{c}{ Source: Processed Data Researcher, 2019 }
\end{tabular}




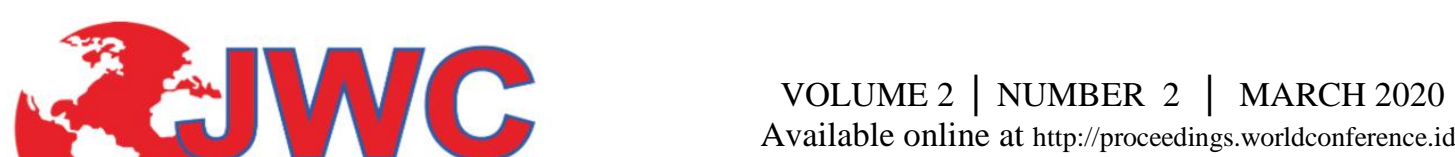

Available online at http://proceedings.worldconference.id.

ISSN: 2656-1174 (online)

\subsection{Normality Test}

Normality test aims to test whether a regression model, the dependent variable, independent variable, or both have a normal distribution or not. A good regression model is data distribution to normal or near normal. In this study, test for normality using the Kolmogorov-Smirnov test, if the significance value> 0.05 then the data is expressed in normal distribution, whereas if the significance value $<0.05$, the data distribution is not normal otherwise. The following table normality test results are obtained.

Table 6. Normality Test Results

One-Sample Kolmogorov-Smirnov Test

\begin{tabular}{llr}
\hline & & Residual unstandardized \\
\hline $\mathrm{N}$ & & 100 \\
\hline Normal Parametersa, b & mean &, 0000000 \\
\cline { 2 - 3 } & Std. deviation & 20.13507914 \\
\hline \multirow{2}{*}{ Most Extreme Differences } & Absolute &, 139 \\
\cline { 2 - 3 } & positive &, 090 \\
\cline { 2 - 3 } & negative &,- 139 \\
\hline Kolmogorov-Smirnov Z & & 1,395 \\
\hline Asymp. Sig. (2-tailed) & &, 041 \\
\hline
\end{tabular}

a. Test distribution is Normal.

b. Calculated from data.

Source: Processed Data Researcher, 2020

The results of the testing of normality above shows that the test results KolmogorovSmirnov seen that the results obtained for the performance of PE and the level of interest, namely $1.395>0.05$, it can be concluded that these data were normally distributed.

\subsection{Analysis Method of Customer Satisfaction Index (CSI)}

\begin{tabular}{|c|c|c|c|c|c|}
\hline \multirow[t]{2}{*}{ Code } & \multirow[t]{2}{*}{ Attribute } & $\begin{array}{l}\text { Median Score } \\
\text { Importacne }\end{array}$ & $\begin{array}{l}\text { weighting } \\
\text { Factors }\end{array}$ & $\begin{array}{c}\text { Median } \\
\text { Satisfaction } \\
\text { Score }\end{array}$ & $\begin{array}{l}\text { weighted } \\
\text { Score }\end{array}$ \\
\hline & & MIS & WF & MSS & WS \\
\hline \multirow[t]{2}{*}{ A. } & STATION BEKASI & & & & \\
\hline & Physical / Tangibles & & & & \\
\hline 1 & The availability of the lounge / seating adequate & 5 & 2,59 & 3 & 7,77 \\
\hline 2 & Availability of facilities prayer rooms for men / women & 5 & 2,59 & 3 & 7,77 \\
\hline 3 & The availability of toilet facilities for men / women & 5 & 2,59 & 4 & 10.36 \\
\hline 4 & $\begin{array}{l}\text { The availability of health posts / tool P3K (wheelchair, stretcher, } \\
\text { etc.) }\end{array}$ & 5 & 2,59 & 3 & 7,77 \\
\hline \multirow[t]{2}{*}{5} & The availability of charging mobile phones and bins & 4 & 2.07 & 4 & 8.29 \\
\hline & Reliability / Reliability & & - & & - \\
\hline \multirow[t]{2}{*}{6} & Ease of ticket purchase & 5 & 2,59 & 4 & 10.36 \\
\hline & Reaction / Responsiveness & & - & & - \\
\hline 7 & $\begin{array}{l}\text { Availability of Information Service Center (min. } 1 \text { person } \\
\text { manning) }\end{array}$ & 5 & 2,59 & 4 & 10.36 \\
\hline \multirow[t]{2}{*}{8} & $\begin{array}{l}\text { Menginfokan skills of officers in the Audio position in the } \\
\text { station wagon }\end{array}$ & 5 & 2,59 & 4 & 10.36 \\
\hline & Certainty / Assurance & & - & & - \\
\hline 9 & $\begin{array}{l}\text { The availability of information on the schedule board / rail } \\
\text { position }\end{array}$ & 5 & 2,59 & 4 & 10.36 \\
\hline
\end{tabular}


VOLUME 2 | NUMBER 2 | MARCH 2020

Available online at http://proceedings.worldconference.id.

ISSN: 2656-1174 (online)

\begin{tabular}{|c|c|c|c|c|c|}
\hline \multirow[t]{2}{*}{ Code } & \multirow[t]{2}{*}{ Attribute } & \multirow{2}{*}{$\begin{array}{c}\begin{array}{c}\text { Median Score } \\
\text { Importacne }\end{array} \\
\text { MIS } \\
\end{array}$} & \multirow{2}{*}{$\begin{array}{c}\begin{array}{c}\text { weighting } \\
\text { Factors }\end{array} \\
\text { WF } \\
\end{array}$} & \multirow{2}{*}{$\begin{array}{c}\begin{array}{c}\text { Median } \\
\text { Satisfaction } \\
\text { Score }\end{array} \\
\text { MSS } \\
\end{array}$} & \multirow{2}{*}{$\begin{array}{c}\begin{array}{c}\text { weighted } \\
\text { Score }\end{array} \\
\text { WS } \\
\end{array}$} \\
\hline & & & & & \\
\hline & Perceived / Emphaty & & - & & - \\
\hline 10 & $\begin{array}{l}\text { The alignment of the platform with the train doors which } \\
\text { facilitate access to up / down passenger (lack of gaps between } \\
\text { the platform) }\end{array}$ & 5 & 2,59 & 4 & 10.36 \\
\hline 11 & $\begin{array}{l}\text { The suitability of the platform width to accommodate the } \\
\text { passengers waiting for the train, at the time of the crowded state }\end{array}$ & 5 & 2,59 & 4 & 10.36 \\
\hline 12 & $\begin{array}{l}\text { And fast response of the security officers in managing incoming } \\
\text { and outgoing passenger trains, on crowded state / emergency }\end{array}$ & 5 & 2,59 & 4 & 10.36 \\
\hline \multirow[t]{2}{*}{ B. } & STATION MANGGARAI & & - & & - \\
\hline & Physical / Tangibles & & - & & - \\
\hline 1 & The availability of the lounge / seating adequate & 5 & 2,59 & 3 & 7,77 \\
\hline 2 & Availability of facilities prayer rooms for men / women & 5 & 2,59 & 4 & 10.36 \\
\hline 3 & The availability of toilet facilities for men / women & 5 & 2,59 & 4 & 10.36 \\
\hline 4 & $\begin{array}{l}\text { The availability of health posts / tool P3K (wheelchair, stretcher, } \\
\text { etc.) }\end{array}$ & 5 & 2,59 & 3.5 & 9.07 \\
\hline \multirow[t]{2}{*}{5} & The availability of charging mobile phones and bins & 4 & 2.07 & 4 & 8.29 \\
\hline & Reliability / Reliability & & - & & - \\
\hline \multirow[t]{2}{*}{6} & Ease of ticket purchase & 5 & 2,59 & 4 & 10.36 \\
\hline & Reaction / Responsiveness & & - & & - \\
\hline 7 & $\begin{array}{l}\text { Availability of Information Service Center (min. } 1 \text { person } \\
\text { manning) }\end{array}$ & 5 & 2,59 & 4 & 10.36 \\
\hline \multirow[t]{2}{*}{8} & $\begin{array}{l}\text { Menginfokan skills of officers in the Audio position in the } \\
\text { station wagon }\end{array}$ & 5 & 2,59 & 4 & 10.36 \\
\hline & Certainty / Assurance & & - & & - \\
\hline \multirow[t]{2}{*}{9} & $\begin{array}{l}\text { The availability of information on the schedule board / rail } \\
\text { position }\end{array}$ & 5 & 2,59 & 4 & 10.36 \\
\hline & Perceived / Emphaty & & - & & - \\
\hline 10 & $\begin{array}{l}\text { The alignment of the platform with the train doors which } \\
\text { facilitate access to up / down passenger (lack of gaps between } \\
\text { the platform) }\end{array}$ & 5 & 2,59 & 4 & 10.36 \\
\hline 11 & $\begin{array}{l}\text { The suitability of the platform width to accommodate the } \\
\text { passengers waiting for the train, at the time of the crowded state }\end{array}$ & 5 & 2,59 & 4 & 10.36 \\
\hline 12 & $\begin{array}{l}\text { And fast response of the security officers in managing incoming } \\
\text { and outgoing passenger trains, on crowded state / emergency }\end{array}$ & 5 & 2,59 & 4 & 10.36 \\
\hline \multirow[t]{2}{*}{ C. } & WAGON & & - & & - \\
\hline & Physical / Tangibles & & - & & - \\
\hline 1 & Availability of seats and cabin areas were clean & 5 & 2,59 & 4 & 10.36 \\
\hline 2 & $\begin{array}{l}\text { Availability of facilities and safety (fire extinguisher, glass } \\
\text { breaker hammer, evacuation instructions, emergency door lever) }\end{array}$ & 5 & 2,59 & 4 & 10.36 \\
\hline 3 & The presence of a security officer in a prepared train set & 5 & 2,59 & 4 & 10.36 \\
\hline \multirow[t]{2}{*}{4} & Availability of handrails for standing passengers & 5 & 2,59 & 4 & 10.36 \\
\hline & Reliability / Reliability & & - & & - \\
\hline \multirow[t]{2}{*}{5} & Incompatibility of arrival and departure schedule & 5 & 2,59 & 3 & 7,77 \\
\hline & Reaction / Responsiveness & & - & & - \\
\hline 6 & $\begin{array}{l}\text { Menginfokan skills of officers in the train and the closest stops } \\
\text { via audio }\end{array}$ & 5 & 2,59 & 4 & 10.36 \\
\hline 7 & P3K availability of equipment carried by security personnel & 5 & 2,59 & 3 & 7,77 \\
\hline \multirow[t]{2}{*}{8} & Their audio notification when doors will be open or closed & 5 & 2,59 & 4 & 10.36 \\
\hline & Certainty / Assurance & & - & & - \\
\hline 9 & $\begin{array}{l}\text { Availability of information (such as sticker) that lists telephone } \\
\text { numbers and SMS complaint }\end{array}$ & 5 & 2,59 & 4 & 10.36 \\
\hline
\end{tabular}


1. Service factor Physical / Tangibles

- $\quad$ Statement of the 7th, safety facilities (APAR, glass breaker hammer, evacuation instructions, emergency door lever)

- $\quad$ Statement of the 9th, handrails for standing passengers

2. Service factor Reaction / Responsiveness

- Statement of the 16th, an audio notification when doors will be open or closed

3. Service factor Assurance / Assurance

- Statement of the $17 \mathrm{th}$, the board information on the schedule / Train position

- $\quad$ Statement of the 19 th, the train route map commuterline

4. Factors Perceived service / Emphaty

- Statement of all 23 priority seating in a commuter train line

- $\quad$ Statement of the 24 th, a sign of the priority seats

- $\quad$ Statement of the 27 th, lighting works fine

\section{Conclusions and Recommendations}

\subsection{Conclusion}

Based on the results of the study, the conclusions in the analysis penumang satisfaction on the performance of services and amenities KRL Commuter Line These stations Bekasi - Manggarai, as follows:

1. From the analysis of the data by using Customer Satisfaction Index (CSI) is obtained, it is known that passenger satisfaction index value obtained was $76.11 \%$. This illustrates that the passengers are satisfied with the performance of services and facilities These stations Commuter Line KRL Bekasi - Manggarai.

2. The quality of service is considered important by consumers based on the results of the method Imperformance Performance Analysis (IPA) there are eight attributes that affect passenger satisfaction, among others: safety facilities (APAR, hammer breaking glass, evacuation signs, lever emergency door), handrails for standing passengers, audio notification when doors will be open or closed, information boards regarding the timing / position of the train, the train commuterline route maps, uduk place in one train commuterline priority, priority seats signs and lighting are considered in line with expectations penumpang.ketanggapan security guards in organize incoming and outgoing passenger trains, on crowded state / emergency, considered less important and less satisfying for passengers.

\subsection{Suggestions}

1. Based on the results obtained, largest recommended to increase the performance of services, because satisfaction is the goal of a service. Therefore, to improve customer satisfaction, PT Kereta Commuter Indonesia as the company that manages the service performance Commuter Line and station facilities, can make improvements optimal and thorough review of all aspects related to quality of service by way of control of the quality of existing services and supplied to customers, especially in the service factor considered high priority and less than satisfactory, especially for the suitability of the arrival and departure Commmuter Line KRL.

2. For further research, is expected to use the questionnaire directly or can be made a comparison between the questionnaire online and in person in order to obtain optimal results.

\section{References}

[1] Franciscus, H., Sukapto, P., \& Sitompul, C. (2012). Development Dimensions of Service Quality Linked to Consumer Satisfaction and Loyalty Services Airline Ticket Online Sales. Neat National Symposium Xi Ft Ums, 10 .

[2] Polyakova, O., \& Mirza, M. (2015). Perceived Service Quality Models: Are They Still Relevant? 24.

\section{Biographies}

Andri Irfan, Rifai Engineering Lecturer at Mercu Buana University, Chair of the Bachelor Program in Civil Engineering at the International University of Batam, Project Manager of the Infrastructure Rehabilitation and Reconstruction Project for affected areas in Palu, head of the PJN Region 3 Work Unit of West Java Province. Specialties: Engineering, Project Management of Transportation

Yuditami Iressa, Fajriliani College Student, University of Mercu Buana Jakarta, Indonesia 